\title{
Strategi Pengembangan Wisata Berbasis Budaya Kerajaan di Pura Pakualaman dan Kampung Wisata Pakualaman
}

\author{
Janu Riyanto \\ Program Pascasarjana Institut Seni Indonesia Yogyakarta \\ email: janukaer@gmail.com
}

\begin{abstract}
Abstrak
Pura Pakualaman dan Kampung Wisata Pakualaman menyimpan potensi besar sebagai destinasi wisata budaya berbasis budaya kerajaan, baik yang bersifat tangible maupun intangible. Komponen atraksi Pura Pakualaman ada yang berupa seni tradisi dan adat istiadat serta ada pula yang berujud benda/bangunan yang punya nilai sejarah tinggi punya keunikan tersendiri. Sedang Kampung Wisata Pakualaman kaya potensi wisata budaya, di antaranya berupa kesenian tradisional, kuliner khas Pakualaman dan tempat-tempat bersejarah. Namun Pura Pakualaman maupun Kampung Pakualaman belum dikembangan secara optimal sebagai destinasi wisata budaya. Penelitian ini difokuskan untuk menggali potensi daya tarik wisata yang dapat dikembangkan sebagai produk wisata di Pura Pakualaman dan Kampung Wisata Pakualaman, hambatan dan kendala yang dihadapi dalam pengembangannya serta strategi pengembangan produk wisata budaya berbasis budaya kerajaan. Penelitian ini merupakan penelitian kualitatif deskriptif, menggunakan sumber data primer dan data sekunder. Hasil penelitian menunjukkan besarnya potensi wisata budaya berbasis kerajaan Pura Pakualaman dan Kampung Wisata Pakualaman belum dimanfaatkan dan dikembangkan secara optimal karena terkendala beberapa hal. Konflik antarkerabat Pura Pakualaman dan masih lemahnya dari sisi tata kelola menjadi hambatan utama pengembangan destinasi wisata budaya ini. Sehingga berdasarkan analisis SWOT, peneliti mengusulkan rencana pengembangan jangka pendek, menengah dan panjang.
\end{abstract}

Kata kunci: pura pakualaman, kampung wisata pakualaman, potensi budaya, strategi pengembangan

\footnotetext{
Abstract

Pura Pakualaman and The Pakualaman Tourism Village saves great potential as a royal culture-based tourist destination both tangible and intangible. Many attraction components of Pura Pakualaman are in the form of traditional arts and customs and the others are referring to objects/buildings that have high historical value. The Pakualaman Tourism Village is rich in cultural tourism, including traditional arts, typical Pakualaman culinary, and historical places. Recently, Pura Pakualaman and Pakualaman villages have not been optimally developed as cultural tourism destinations. This research is focused on exploring the potential of tourist attraction that can be developed as a tourism product in Pura Pakualaman
} 
Jurnal Tata Kelola Seni-Vol. 5 No. 1 Juni 2019

p-ISSN 2442-9589, e-ISSN 2614-7009

and Pakualaman Tourism Village, obstacles and constraints faced in its development and development strategies for cultural tourism products based on royal culture. This research is descriptive qualitative research, using primary data sources and secondary data. The results of the research show that the magnitude of the kingdom-based cultural tourism potential of Pura Pakualaman and Pakualaman Tourism Village has not been optimally utilized and developed because of several constraints. The inter-friend conflict of the Pura Pakualaman and the weak governance aspect is the main obstacle to the development of this cultural tourism destination. So based on the SWOT analysis, researchers propose development plans for the short, medium and long term.

Keywords: Pura Pakualaman, Pakualaman Tourism Village, cultural potential, development strategy

\section{PENDAHULUAN}

Sesuai dengan kondisi geografis dan potensi yang dimiliki, pengembangan pariwisata di Kota Yogyakarta lebih efektif berorientasi pada budaya, baik yang bersifat tangible (benda) maupun intangible (tak benda). Selain Kraton Yogyakarta yang sudah menjadi icon wisata, sebenarnya Yogyakarta juga punya tempat wisata yang sama-sama berbasis warisan budaya kerajaan, yakni Kadipaten Pakualaman. Namun Kadipaten Pakualaman belum dikembangkan secara optimal sehingga lebih sebagai simbol kerajaan di masa lalu saja.

Padahal kawasan Pura Pakualaman yang menjadi bagian dari area Kampung Wisata Pakualam yang menyimpan banyak potensi berharga, berupa seni budaya/tradisi maupun benda/bangunan/heritage bernilai sejarah tinggi. Sesuai dengan Visi Pembangunan DIY pada Tahun 2012-2025 yang kemudian dijabarkan didalam misi bahwa perlunya mewujudkan kepariwisataan yang kreatif dan inovatif, maka sudah saatnya kawasan Pura Pakualaman lebih dikembangkan sebagai salah satu destinasi wisata budaya unggulan di Yogyakarta.

Pura Pakualaman yang terletak di wilayah kelurahan Purwokinanti dan sebagian masuk wilayah Kalurahan Gunungketur, Kecamatan Pakualaman, Kota Yogyakarta merupakan salah satu bekas kerajaan yang menyimpan potensi besar untuk dikembangkan sebagai destinasi wisata budaya. Keberadaan Kampung Wisata Pakualaman yang dirintis sejak tahun 2013, sebenarnya sangat mendukung pengembangan pariwisata di kawasan Pura Pakualaman. Pengelola Kampung Wisata Pakualaman sebenarnya telah berusaha memanfaatkan keunggulan potensi budaya warisan Kadipaten Pakualaman untuk menarik wisatawan, baik domestik maupun manca negara. Namun masih banyak kendala yang dihadapi pengelola Kampung Wisata Pakualaman untuk mengoptimalkan potensi budaya Pura Pakualaman dan masyarakatnya guna menarik minat wisatawan.

Selain keterbatasan Sumber Daya Manusia (SDM) dalam mengelola Kampung Wisata Pakualaman, akses yang terbatas untuk menjadikan simbol-simbol Kadipaten Pakualaman dengan peninggalan-peninggalan yang bernilai sejarah tinggi sebagai obyek wisata, menjadi kendala utama dalam pengembangan wisata berbasis budaya di wilayah ini. Di samping 
partisipasi dan kesadaran masyarakat yang masih dalam kategori rendah untuk pengembangan pariwisata berbasis budaya di wilayah ini.

Berbeda dengan Kraton Yogyakarta yang dibuka umum sebagai tempat wisata, Pura Pakualaman belum dibuka secara luas untuk umum. Pengunjug hanya terbatas pada waktuwaktu tertentu dan tidak dipungut biaya. Kondisi ini membuat Pura Pakualaman belum dapat dikembangkan menjadi destinasi wisata budaya berbasis keunggulan warisan kerajaan yang dapat menyedot banyak wisatawan seperti Kraton Yogyakarta.

Berdasar hal itulah peneliti ingin melakukan kajian lebih mendalam terhadap potensi wisata berbasis warisan budaya kerajaan (Kadipaten Pakualaman) yang dimiliki Pura Pakualaman dan Kampung Wisata Pakualaman serta model pengembangan yang telah dilakukan selama ini untuk menarik minat wisatawan berkunjung. Di samping mengetahui kedala-kendala yang dihadapi selama ini dalam pengembangan wisata budaya tersebut untuk selanjutnya menyusun strategi pengembangan dalam jangka pendek, menengah maupun panjang berdasarkan analisis SWOT.

\section{Landasan Teori}

Pariwisata diartikan sebagai suatu aktivitas yang dilakukan oleh wisatawan untuk bepergian ke suatu tempat tujuan wisata di luar keseharian dan lingkungan tempat tinggalnya untuk melakukan persinggahan yang sifatnya sementara waktu dari tempat tinggal, yang didorong beberapa keperluan tanpa untuk bermaksud mencari nafkah, namun didasarkan untuk mendapatkan kesenangan, disertai untuk menikmati berbagai hiburan yang dapat melepaskan lelah dan menghasilkan pengalaman perjalanan berwisata dan pelayanan keramah-tamahan (Inskeep, Edward, 1991).

Jenis-jenis Pariwisata menurut Spillane (1987):

\section{Pariwisata untuk Menikmati Perjalanan (Pleasure Tourism)}

Jenis pariwisata ini dilakukan oleh orang-orang yang meninggalkan tempat tinggalnya untuk berlibur, untuk mencari udara segar yang baru, untuk memenuhi kehendak ingin tahunya, untuk mengendorkan ketegangan sarafnya, untuk melihat sesuatu yang baru, untuk menikmati keindahan alam, atau bahkan untuk mendapatkan ketenangan dan kedamaian di daerah luar kota.

\section{Pariwisata untuk Rekreasi (Recreation Tourism)}

Jenis pariwisata ini dilakukan oleh orang-orang yang menghendaki pemanfaatan harihari liburnya untuk beristirahat, untuk memulihkan kembali kesegaran jasmani dan rohaninya, yang ingin menyegarkan keletihan dan kelelahannya.

3. Pariwisata untuk Kebudayaan (Cultural Tourism)

Jenis pariwisata ini dilakukan karena adanya keinginan untuk mempelajari adat istiadat, kelembagaan, dan cara hidup rakyat daerah lain selain itu untuk mengunjungi monumen bersejarah, peninggalan peradaban masa lalu, pusat-pusat kesenian, pusat-pusat keagamaan, atau untuk ikut serta dalam festival-festival seni musik, teater, tarian rakyat, dan lain-lain. 
Jurnal Tata Kelola Seni-Vol. 5 No. 1 Juni 2019

p-ISSN 2442-9589, e-ISSN 2614-7009

4. Pariwisata untuk Olahraga (Sports Tourism)

Jenis ini dapat dibagi dalam dua kategori:

a. Big Sports Event, pariwisata yang dilakukan karena adanya peristiwa-peristiwa olahraga besar seperti Olympiade Games, World Cup, dan lain-lain.

b. Sporting Tourism of the Practitioner, yaitu pariwisata olahraga bagi mereka yang ingin berlatih dan mempraktikkan sendiri, seperti pendakian gunung, olahraga naik kuda, dan lainlain.

5. Pariwisata untuk Urusan Usaha Dagang (Business Tourism)

Perjalanan usaha ini adalah bentuk professional travel atau perjalanan karena ada kaitannya dengan pekerjaan atau jabatan yang tidak memberikan kepada pelakunya baik pilihan daerah tujuan maupun pilihan waktu perjalanan.

6. Pariwisata untuk Berkonvensi (Convention Tourism)

Konvensi sering dihadiri oleh ratusan dan bahkan ribuan peserta yang biasanya tinggal beberapa hari di kota atau negara penyelenggara.

Ada empat komponen atau aspek daya tari wisata yang harus diperhatikan dalam pengembangan destinasi wisata, termasuk wisata budaya. Aspek-aspek tersebut adalah sebagai berikut:

1. Attraction (daya tarik)

Daerah tujuan wisata untuk menarik wisatawan pasti memiliki daya tarik, baik daya tarik berupa alam maupun masyarakat dan budayanya.

2. Accesability (aksesibilitas)

Accesability dimaksudkan agar wisatawan domestik dan mancanegara dapat dengan mudah dalam pencapaian tujuan ke tempat wisata.

3. Amenities (amenitas/fasilitas)

Amenities memang menjadi salah satu syarat daerah tujuan wisata agar wisatawan dapat dengan kerasan tinggal lebih lama di salah satu objek wisata. Biasanya akomodasi yang diinginkan wisatawan berkunjung adalah hotel dan restoran yang mudah dijangkau, serta bisa memenuhi apa yang wisatawan inginkan selama berada di objek wisata yang dikunjunginya.

4. Ancillary (kelembagaan/tambahan)

Adanya lembaga pariwisata, wisatawan akan semakin sering mengunjungi dan mencari daerah tujuan wisata apabila di daerah tersebut wisatawan dapat merasakan keamanan, (protection of tourism) dan terlindungi.

\section{METODE}

1. Objek Penelitian

Pura Pakualaman dan Kampung Wisata Pakualaman yang secara geografis terletak di Kelurahan Gunungketur dan Kalurahan Purwokinanti, Kecamatan Pakualaman, Kota Yogyakarta dengan segala potensi yang dimiliki, terutama yang berbasis warisan budaya kerajaan (Kadipaten Pakualaman). 


\section{Subjek Penelitian}

a. Penghageng Pambudidaya Kadipaten Pakualaman K.P.H Kusumo Parastho.

b. Staf Kapanitran Kadipaten Pakualaman K.M.T Sestrodiprojo.

c. Ketua Tim Pengelola Kampung Wisata Pakualaman Rudi Supriyadi.

d. Sekretaris Tim Pengelola Kampung Wisata Pakualaman Arif Hidayat.

3. Teknik Pengumpulan Data

Penelitian ini menggunakan sumber data primer dan data sekunder. Sumber data primer adalah data hasil observasi lapangan, wawancara, dan dokumentasi. Sedangkan data sekunder adalah semua referensi yang berkaitan dengan model pengembangan model pengembangan potensi wisata berbasis warisan budaya kerajaan di Pura Pakualaman dan Kampung Wisata Pakualaman.

4. Analisis Data

Analisis data menggunakan model interaktif sebagaimana digunakan Miles dan Huberman dalam Sugiyono (2008) yang terdiri dari empat hal utama, yakni pengumpulan data, reduksi data, penyajian data, dan penarikan kesimpulan atau verifikasi. Untuk mempertajam analisis sebagai pijakan untuk menyusun usulan strategi pengembangan, digunanan analisis SWOT. Analisis SWOT adalah metode perencanaan strategis yang digunakan untuk mengevaluasi kekuatan (Strengths), kelemahan (Weaknesses), peluang (Opportunities), dan ancaman (Threats) dalam suatu proyek atau suatu spekulasi bisnis.

\section{HASIL DAN PEMBAHASAN}

Pura Pakualaman merupakan satu dari dua istana yang ada di Yogyakarta. Berdirinya Kadipaten Pakualaman tidak lepas dari polemik yang melanda Kasultanan Yogyakarta semasa era Sultan Hamengkubuwono (HB) II. Ketika itu tanah Jawa secara bergantian dikuasai Belanda dan Inggris pada awal dekade kedua abad ke-19.

Melalui perjanjian pada tahun 1813 dengan pihak Inggris, Sultan HB II diwajibkan menyerahkan sebagian wilayahnya keapada Pangeran Notokusumo. Pangeran ini adalah adik tiri Sultan HB II yang membantu Inggris memadamkam pergolakan di Yogyakarta kala itu. Sebagai sesama putra Sultan HB I, Notokusumo merasa berhak menikmati kekuasaan. Adapun wilayah yang diserahkan HB II kepada Notokusumo meliputi area khusus di dalam Kota Yogyakarta dan kawasan yang disebut Adikarto (sekarang terletak di Kabupaten Kulonprogo bagian selatan) seluas 4.000 cacah.

Selanjutnya berdasar kontrak politik yang disepakati pada 17 Maret 1813 antara wakil Inggris dan Pangeran Notokusumo, maka berdirilah suatu pemerintahan baru di Yogyakarta, di luar kasultanan yang dipimpin oleh sultan, bernama Kadipaten Pakualaman. Tanggal 29 Juni 1813, Pangeran Notokusumo dinobatkan sebagai penguasa Pakualaman dengan gelar Paku Alam I. Oleh Inggris, Paku Alam I sebagai pangeran merdeka, diberikan tanah, tunjangan, pasukan, hak memungut pajak sertah hak tahta turun temurun. 
Jurnal Tata Kelola Seni-Vol. 5 No. 1 Juni 2019

p-ISSN 2442-9589, e-ISSN 2614-7009

Pura Pakualaman terletak di Kelurahan Purwokinanti dan Kalurahan Gunungketur, Kecamatan Pakualaman, Kota Yogyakarta. Kawasan ini diapit oleh jalan umum di sisi utara (Jl. Purwanggan), timur (Jl. Harjono), dan selatan (Jl. Sewandanan). Gerbang istana Paku Alaman terdapat di sisi selatan (gerbang utama) dan sisi utara (sudah ditutup, namun masih ada bekas-bekasnya). Puro Pakualaman saat ini menjadi tempat kediaman resmi Sri Paduka Paku Alam X, yang juga wakil gubernur Provinsi Daerah Istimewa Yogyakarta.

Pura Pakualaman kaya akan potensi wisata budaya, baik yang berwujud benda/bangunan bernilai sejarah tinggi maupun budaya seni tradisi yang masih dijaga kelestariannya. Bangungunan di komplek Pura Pakualaman terdiri dari:

1. Pintu Gerbang/Regol Danawara

Merupakan akses masuk utama ke Pura Pakualaman dari arah Selatan (dari alun-alun Sewandanan). Pendapa/Bangsal Sewatama.

\section{Bangsal Sewatama}

Merupakan pendapa atau bangunan terbuka yang dalam rumah tradisional Jawa termasuk dalam bangunan publik yang biasanya dipakai untuk pagelaran kesenian tradisional.

\section{Ndalem Ageng Prabasuyasa}

Merupakan bangunan inti dari Pura Pakualaman. Bangunan ini terletak persis di utara Bangsal Sewatama. Di Ndalem Ageng Prabasuysa ini terdapat tiga ruang utama, yakni Senthong Tengah (pasren), Senthong Kulon (tempat pusaka) yang sebagian besar merupakan keris, Senthong Wetan yang merupakan ruang biasa.

\section{Bangsal Sewarengga}

Merupakan bangunan terbuka (tanpa dinding) terletak persis di belakang atau di sebelah utara Ndalem Ageng Prabasuyasa. Bangsal dengan ukuran relatif kecil mempunyai atap dengan bentuk joglo apitan. Sekarang bangsal ini digunakan untuk memandikan pusaka dan kadang-kadang dipakai sebagai tempat berkumpul/rapat para keluarga Kadipaten pakualaman.

\section{Gedhong Purworetna}

Bangunan yang sangat indah ini dibangun pada masa Paku Alam VII dibantu oleh Paku Buwono X. Bangunan Gedhong Purwooretno ini dihiasi dengan ukiran-ukiran kaya tembus pandang (krawangan). Di gedung inilah Paku Buwono X tinggal jika sedang berkunjung ke Pura Pakualaman. Bangsal Purworetna ini dihiasi dengan ukiran-ukiran kayu tembus pandang (krawangan).

\section{Bangsal Parangkarsa}

Bangsal yang terletak di sisi barat Bangsal Sewatama ini berfungsi sebagai tempat persiapan perkawinan putra/putri paku Alam, terutama pada saat midodareni.

\section{Gedhong Maerakaca}

Salah satu bangunan yang tidak tampak mencolok secara visual karena letaknya di bagian belakang, namun sangat menarik dari sisi keberadaanya. Gedhong Maerakaca dibangun oleh Van der Beek. Konon permaisuri Paku Alam VII sangat menyukai bangunan ini. 


\section{Masjid Besar Pakualaman}

Di luar kompleks Puro, tepatnya di sudut barat laut alun-alun Sewandanan, terdapat sebuah Masjid. Pada prasasti di sebelah utara tertoreh sengkalan: Pandhita Obah Sabda Tunggal yang menunjukkan tahun Jawa 1767 (1839 Masehi).

\section{Museum Puro Pakualaman}

Merupakan jenis museum bercorak khusus, yakni museum yang menggambarkan budaya Istana Paku Alaman dan sistem pemerintahan Praja Paku Alaman. Lokasi museum yang menempatai 3 buah ruangan, masing-masing berukuran $8 \times 14$ meter, terletak di dalam komplek Pura Pakualaman di bagaian sayap muka sebelah timur. Jalan masuk melewati Regol Wiwara Kusumo (pintu gerbang). Di dalam museum terdapat ratusan koleksi benda-denda bersejarah yang merupakan jejak sejarah Kadipaten Pakualaman sejak diperintah Paku Alam I.

\section{Perpustakaan}

Perpustakaan terletak di komplek Pura Pakualaman menyimpan dokumen dan naskahnaskah kuna sejak pemerintahan Paku Alam II dan koleksi buku-buku tentang sejarah dan perkembangan Kadipaten Pakualaman. Tidak kurang dari 250 koleksi buku dan manuskrip kuna bisa dijumpai di perpustakaan ini.

Sedangkan potensi wisata Pura Pakualaman berupa kesenian tradisi meliputi seni tari, karawitan, wayang, kesusasteraan dan upacara adat. Seni tari berkembang sejak pemerintahan Paku Alam I hingga IX. Tarian ini di antaranya bernama Srimpi Gandrung Winangun, Srimpi Ela-ela, Bekan Dhadhap, Beksan Paris dan Beksan Larung. Untuk seni karawitan, Purao Pakualam punya kelompok yang melakukan latihan rutin setiap hari Senin dan Kamis sore dengan menyiapkan gending-gending untuk acara-acara yang diselenggarakan Kadipaten Pakualaman. Untuk upacara adat di Pura Pakualaman dapat dikelompokkan menjadi dua, yakni pertama: upacara adat yang berkaitan dengan dasar kehidupan manusia mulai dari prakelahiran, kelahiran, remaja, dewasa sampau kematian. Kedua: upacara adat yang berkaitan dengan peringatan, kehidupan keagamaan, benda dan lingkungan.

Pengelolaan Pura Pakualaman disebut Tata Pamong yang dilakukan oleh tim pengelola yang dibentuk Paku Alam dan dipimpin langsung oleh Paku Alam. Tata Pamong terdiri dari bagian-bagian yang mengurusi bidangnya masing-masing. Namun Tata Pamong ini belum berfungsi optimal, termasuk dalam mengelola wisata budayanya. Besarnya potensi yang dimiliki Puro Pakualaman berupa benda-benda bernilai sejarah tinggi dengan kekhasan budaya sebagai salah satu bekas Kadipaten di Pulau Jawa pun, belum dimanfaatkan secara optimal sebagai tempat wisata seperti Kraton Yogyakarta.

Menurut Penghageng Pambudidaya Kadipaten Pakualaman KPH Kusumo Parastho, meski dalam sistem Tata Pamong Paku Alam X ada Kawedanan Budaya dan Pariwisata, namun Pura Pakualaman belum dikelola secara optimal sebagai salah satu destinasi wisata berbasis peninggalan kerajaan yang kaya akan benda-benda bersejarah serta budaya-budaya tradisi asli kadipaten. Belum optimalnya pengelolaan Pura Pakualaman sebagai tempat wisata itu bisa 
Jurnal Tata Kelola Seni-Vol. 5 No. 1 Juni 2019

p-ISSN 2442-9589, e-ISSN 2614-7009

dilihat dari berbagai segi, baik dari pemeliharaan asset, manajemen pengelolaan maupun promosinya.

KPH Kusumo Parastho mengakui pengelolaan Pura Pakualaman sebagai tempat wisata tidak sehat. Banyak kendala yang dihadapi, di antaranya konflik yang dihadapi di lingkungan kerabat Paku Alam sendiri. Misalnya untuk museum hingga saat ini masih dikuasai keluarga KPH H Angling Kusumo yang hingga saat ini masih berseteru dengan Paku Alam X. Sehingga pihak Paku Alam X tidak dapat leluasa mengelola museum ini. Kubu Anglingkusumo pun terkesan menelantarkan museum ini dan lebih sebagai simbol bahwa pihaknya masih menguasai salah satu asset dari Pura Pakualaman untuk melegitimasi haknya untuk diangkat menjadi Paku Alam.

Konflik kerabat Paku Alam yang berlarut-larut tersebut menjadi salah satu hambatan utama pengembangan pariwisatan di komplek Pura Pakualaman. Akibat konflik ini, tidak semua asset Pura Pakualaman bisa dikeloloa oleh Tata Pamong, sehinga semakin sulit mengoptimalkan potensi yang dimiliki. Terlebih asset yang dikuasai kubu Anglingkusumo merupakan benda atau baran-barang bersejarah yang punya daya tarik tinggi yang tersimpan di museum.

Selain konflik dan sengketa antarkerabat Paku Alam tersebut, ada sejumlah kendala lainnya untuk pengembangan pariwisata di kawasan Pura Pakualaman. Di antaranya Paku Alam X sendiri yang masih ingin menjaga privasinya sebagai raja. Beliau tidak berkenan jika masyarakat umum dengan bebas masuk di area-area tertentu Pura Pakualaman yang sebenarnya merupakan tempat-tempat yang punya nilai sejarah tinggi dan menarik untuk dikunjungi. Namun Paku Alam X tidak ingin area itu menjadi 'jakjakan' dengan tetap ingin menjaganya sebagai tempat sakral bagi keluarga besar Paku Alam.

Untuk itu pengembangan pariwisata direncanakan di luar area Pura Pakualaman, yakni di bekas Bioskop Permata di Jalan Sultan Agung, Gunungketur, Pakualaman, Yogyakarta yang rencananya akan digunakan sebagai museum. Sedangkan di Kepatihan Jl. Masjid No.5, Purwokinanti, Pakualaman yang sekarang digunakan untuk Akper Notokusumo, nantinya bakal digunakan sebagai pagelaran seni budaya, sekaligus untuk melestarikan tradisi dan budaya Pura Pakualaman.

Besarnya potensi wisata budaya juga dimiliki Kampung Wisata Pakualaman yang terletak di Kelurahan Gunungketur, Kecamatan Pakualaman, Kota Yogyakarta. Ada sejumlah bentuk/paket wisata yang ditawarkan, baik berupa budaya warisan Kadipeten Pakualaman, kulier maupun sejumlah bangunan/heritage yang punya nilai sejarah tinggi. Bentuk/paket wisata ini di antaranya, makanan khas yang diproduksi oleh para UMKM yang sudah mempunyai IUM (Ijin Usaha Mikro) seperti Pie Susu berlabel Quanta, Jamu Ginggang yang legendaris, enting-enting gepuk dan yang lainnya.

Paket lainnnya, melihat proses pengolahan kopi yang dilakukan warga setempat di Jalan Masjid No. 10 mulai pukul 20.00 hingga 24.00 WIB. Kopi berlabel "Yepmum" ini diperoleh dari petani kopi di Papua. Gudeg Permata Bu Pujo yang terletak di Jalan Gajah Mada No. 2 yang menjadi salah satu icon kuliner di Kampung Wisata Pakualaman. Foodcourt 
Pujosewa, yaitu pasar kuliner yang menyajikan berbagai macam kuliner. Disamping kegiatan tradisi kesenian yang menarik lainnya, diantaranya Gunungan di setiap Idul fitri dan Idul adha, sungkeman, hadeging nagari, tingalan ndalem, dan jemparingan yang dilaksanakan setiap Sabtu Kliwon di sebelah barat Pakualaman.

Untuk pengelolaan sistem pengelolaan Kampung Wisata Pakualaman, berdasarkan hasil wawancara dengan Sekretaris Tim Pengelola Kampung Wisata Pakualaman Arif Hidayat, dilakukan oleh tim pengelola yang dibentuk sejak perintisan kampung ini pada 2013 lalu dengan ketuanya, Rudi Supriyadi. Namun karena alasan kesibukan pekerjaan, Rudi saat ini sudah tidak begitu aktif. Perannya sebagai ketua tim pengelola lebih banyak dijalankan Arif Hidayat yang menjabat sekretaris.

Tim pengelola ini dibentuk dalam masa jabatan 5 tahun dan seharusnya sudah ada pergantian pengurus pada 2018 lalu, namun hingga kini masih dijalankan pengurus lama. Tim pengelola ditetapkan melalui Surat Keputusan (SK) Lurah Gunungketur. Tim pengelola ini lah yang bertanggung jawab penuh terhadap pengelolaan Kampung Wisata Pakualaman.

Tim Pengelola punya sekretariat sebagai tempat untuk mengendalikan Kampung Wisata Pakualaman yamg beralamat di Jl. Masjid No. 44 Gunungketur, Pakualaman, Yogyakarta 55111. Kegiatan pengelolaan ini meliputi koordinasi, pemasaran/promosi, guiding dan kerja sama. Namun setiap kegiatan yang dilaksanakan belum berfungsi optimal karena terkendala banyak hal, termasuk faktor SDM dari sisi kuantitas maupun kualitas.

Tim Pengelola Kampung Wisata Pakualaman tidak punya hubungan secara organsisasi dengan pengelola Kadipaten Pakualaman. Sehingga Tim Pengelola Kampung Wisata Pakualaman tidak punya wewenang atau otoritas untuk ikut mengelola potensi wisata yang dimiliki Kadipaten Pakualaman yang punya banyak potensi wisata sejarah. Keduanya hanya bekerja sama untuk mengelola beberapa event budaya.

Adapun analisis SWOT terhadap 4 komponen pariwisata, yakni atraksi, amenitas, aksesibilitas dan Ancilliary (Kelembagaan) terhadap Pura Pakualaman dan Kampung Wisata Pakualaman sebagai pijakan untuk menyusun rencana strategi pengembangannya, sebagai berikut: Kekuatan (Strengths) aspek atraksi dari Pura Pakualaman adalah keunikan budaya yang dimiliki, berbasis warisan budaya kerajaan, baik yang tangible maupun intangible. Namun ada sejumlah kelemahan (Weaknesses) aspek atraksi Pura Pakualaman, yakni belum tersentuh inovasi dan teknologi, beberapa even budaya/upacara adat tidak bisa disaksikan setiap saat karena hanya dilaksanakan di waktu-waktu tertentu, benda-benda/bangunan di komplek Pura Pakualaman tidak terawat dengan baik sehingga menurunkan sisi keindahan dan estetikanya serta belum teridentifikasi dan tertata dengan baik serta belum terlabeli.

Semakin banyaknya wisatawan yang tertarik untuk mengunjungi wisata budaya berbasis warisan kerajaan menjadi peluang (Opportunities) pengembangan Pura Pakualaman maupun Kampung Wisata Pakualaman dari aspek atraksi. Disamping tidak banyak destinasi wisata yang berbasis warisan budaya kerajaan di tanah air juga membuka peluang pengembangan Pura Pakualaman. 
Jurnal Tata Kelola Seni-Vol. 5 No. 1 Juni 2019

p-ISSN 2442-9589, e-ISSN 2614-7009

Sejumlah ancaman (Threats) yang dihadapi Pura Pakualaman dan Kampung Wisata Pakualaman dari sisi atraksi, semakin beragamnya destinasi wisata yang menawarkan berbagai macam keunggulan daya tarik dan pesatnya perkembangan zaman dan teknologi yang mengikis dan menggusur tradisi-tradisi warisan kerajaan. Sehingga dibutuhakan terobosan dan inovasi untuk meningkatkan daya tarik atraksi di Pura Pakualaman.

Kekuatan Pura Pakualaman dan Kampung Wisata Pakualaman dari aspek amenitas, di antaranya terletak di wilayah perkotaan sehingga dekat dengan lokasi-lokasi pendukung, seperti tempat makan/restoran, homestay/penginapan dan hotel-hotel berbagai tipe. Kelemahannya dari aspek amenitas, belum ada toilet khusus untuk wisatawan, belum ada pos pengamanan yang khusus melayani wisatawan, Lahan parkir yang terbatas dan tidak tersedianya rest area khusus untuk wisatawan. Sedangkan peluang dari aspek amenitas ini, kawasan Pura Pakualaman dan Kampung Wisata yang terletak di tengah pemukiman pendududuk memungkinan banyaknya keterlibatan masyarakat dalam pengembangannya dan banyaknya fasilitas pendukung bisa menahan wisatawan untuk tinggal lebih lama. Ancaman yang dihadapi dari aspek amenitas, kawasan pertokoan dan kegiatan bisnis lainnya yang terus berkembang sehingga mengancam kenyamanan wisatawan di kawasan Pura Pakualaman dan kurangnya pastisipasi masyarakat setempat untuk ikut mendukung penyedian amenitas guna pengembangan wisata Pura Pakualaman.

Kekuatan Pura Pakualaman dan Kampung Wisata Pakualaman dari aspek aksesibiltas, mudah dijangkau dengan banyak moda angkutan, dan akses jalan menuju kawasan ini bisa dari segala penjuru. Jalan juga sudah bagus beraspal yang memudahkan untuk memasuki kawasan Pura Pakualaman serta waktu tempuh yang relatif singkat dari terminal bus, stasiun kereta api maupun bandara memberi kemudahan dan kenyamanan pengunjung dari aspek aksesibilitas. Kelemahannya, terletak di tengah kota yang rawan kemacetan. Kendaraan-kendaraan besar seperti bus kesulitan untuk masuk sampai ke kawasan karena beberapa ruas jalan cukup sempit. Sedangkan peluang dari aspek aksesibilitas, akses masuk yang masih bisa ditata dan dikembangkan untuk kemudahan dan kenyaman wisatawan dan banyaknya moda transportasi yang bisa menjangkau kawasan Pura Pakualaman. Ancaman yang dihadapi dari aspek aksesibilitas, penataan Kota yang kurang mengindahkan akses masuk ke kawasan Pura Pakualaman dan arus lalu lintas di jalan protokol di sekitar kawasan yang semakin macet.

Kekuatan Pura Pakualaman dari aspek Ancilliary, sudah ada Sistem Tata Pamong yang mengelola asset dan potensi pariwisata budaya dan punya sumber dana dari bantuan Dana Keistimewaan untuk pemeliharaan asset budaya dan pengembangannya. Selain itu sudah terjalin kerja sama dengan beberapa stakeholders untuk pemeliharaan dan pemanfaatan asset serta Paku Alam yang secara otomastis menjabat wakil gubernur DIY. Kelemahannya, sistem pengelolaan asset wisata budaya yang belum tertata dengan baik dan belum ada tim yang secara khusus bertanggung jawab penuh terhadap pengelolaan wisata budaya. Sedangkan status Daerah Istimewa yang memungkinkan masuknya Dana Keistimewaan lebih besar untuk pengembangan wawasan memberi peluang (pengembangan Pura Pakualaman dari aspek Ancilliary. 
Berdasar analisis SWOT itu, usulan Strategi Pengembangan Pura Pakualaman dan Kampung Wisata Pakualaman terdiri dari 3 kategori, yakni jangka pendek, menengah dan panjang. Strategi Pengembangan Jangka Pendek dilakukan dalam kurun waktu enam bulan pertama hingga satu tahun pertama dengan sasaran utama membenahi pengelolaan pariwisata Pura Pakualaman yang terintegrasi dengan Kampung Wisata Pakualaman. Paket-paket wisata yang ditawarkan Kampung Wisata Pakualaman juga harus terintegrasi dengan potensi-potensi wisata yang dimiliki Pura Pakualaman.

Untuk meningkatkan kinerja Tim Pengelola Kampung Wisata perlu dilakukan penyegaran personil dengan mengganti personil-personil yang selama ini tidak aktif. Pola penggantiannya bisa dilakukan secara terbuka melalui pemilihan yang melibatkan masyarakat. Disamping melibatkan pula Tata Pamong Pura Pakulaman, yakni bagian Kawedanan Budaya lan Pariwisata. Tim Pengelola Kampung Wisata Pakualaman bersama Kawedanan Budaya lan Pariwisata Pura Pakualaman membuat perencanaan pengelolaan pariwisata Kampung Wisata Pakualaman yang terintegrasi dengan pengelolaan Pura Pakualaman, bisa diawali dengan kajian dan evaluasi terhadap pengelolaan sebelumnya. Rekonsiliasi antara dua kubu yang terlibat konflik, antara kubu Paku Alam X dan KPH Angling Kusumo juga mendesak dilakukan dengan mediator yang tepat.

Perencanaan pengelolaan Kampung Wisata Pakualaman yang terintegrasi dengan Puro Pakualaman ini sekaligus menyusun dan menentukan format kerja sama dan bagi hasil. Selain itu mengidentifikasi paket-paket wisata yang bisa dijalankan masing-masing pengelola dan paket wisata yang harus terintegrasi di antara kedua pengelola (Kampung Wisata Pakualaman dan Pura Pakualaman).

Strategi Pengembangan jangka menengah dilakukan dalam waktu 1 hingga 3 tahun ke depan yang sudah mengarah pada pembenahan amenitas dan aksesibilitas yang bersifat pembangunan fisik. Pembenahan ini sudah melibatkan Pemerintah Kota (Pemkot) Yogyakarta dan Pemerintah Daerah (Pemda) DIY. Pembenahan amenitas menyangkut penyediaan beberapa fasilitas, di antaranya toilet umum, rest area, penataan lahan parkir untuk kenyamanan pengunjung dan pos informasi bersama yang melayani informasi wisata yang dikelola Kampung Wisata Pakualaman atau Pura Pakualaman maupun yang dikelola bersama.

Penataan dan penertiban pedagang yang menjadi bagian dari paket wisatata Kampung Pakualaman dalam bentuk wisata kuliner. Pedagang-pedagang yang masuk paket ini dipisahkan dengan pedagang untuk masyarakat umum. Termasuk menempatkan sentra souvenir khusus untuk para wisatawan yang menyatu atau tidak jauh dari kawasan Pura Pakualaman dan Kampung Wisata Pakualaman.

Pembenahan dari sisi aksesibilitas menyangkut pengaturan jalur masuk khusus wisatawan ke kawasan Pura Pakualaman dan Kampung Wisata Pura Pakualaman yang terpisah dengan masyarakat umum. Ini untuk memberi kenyaman kepada wisatawan. Jalur masuk ini langsung terkoneksi dengan area atau kantung-kantung parkir yang harus disediakan. Penataan aksessibilitas ini juga melibatkan pihak-pihak terkait, misalnya Dinas Perhubungan Kota Yogyakarta. 
Jurnal Tata Kelola Seni-Vol. 5 No. 1 Juni 2019

p-ISSN 2442-9589, e-ISSN 2614-7009

Untuk strategi pengembangan jangka panjang diproyeksikan dalam waktu 3 sampai 5 tahun dengan sasaran membuat kawasan wisata budaya terpadu Pakualaman dengan mengoptimalkan semua potensi yang ada disertai pengelolaan professional dan modern. Kawasan wisata terpadu ini tidak hanya terfokus di komplek Pura Pakualaman saja, namun juga mengoptimalkan pemanfaatkan asset Pura Pakualaman yang tersebar di wilayah Kecamatan Pura Pakualaman. Seperti yang telah direncanakan Tata Pamong Pura Pakualaman untuk menadikan gedung eks Bioskop Permata yang terletak di Jl. Sultan Agung No.17, Gunungketur, Pakualaman, Kota Yogyakarta sebagai museum yang menyimpan benda-benda atau barang-barang bersejarah Pura Pakualaman. Selain itu menjadikan Kepatihan yang beralamat di Jl. Masjid No.5, Purwokinanti, Pakualaman yang kini masih ditempati Akper Notokusumo sebagai pusat pagelaran budaya.

Kawasan Wisata Terpadu itu harus dikelola secara profesional, termasuk sistem tiketing ang lebih modern dengan sentuhan teknologi, transportasi yang terhubung ke tiga tempat tersebut dan kelengkapan aspek amenitasnya. Paket wisatanya (komponen atraksi) pun dibuat lebih variatif dan inovatif sehingga meningkatkan daya tari bagi wisatawan. Muaranya pada peningkatan jumlah kunjungan wisata.

Model Pengembangan Kawasan Wisata Terpadu Pakualaman

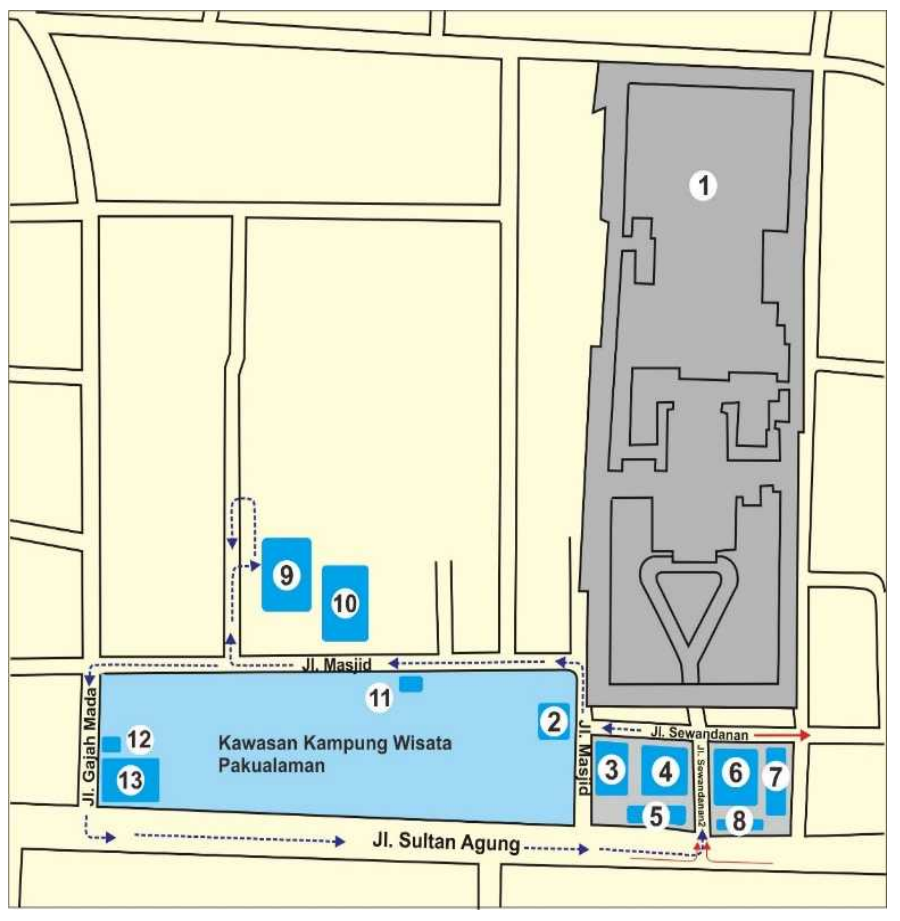

Keterangan Gamabar:

1. Kawasan Pura Pakualaman

2. Masjid Besar Pakualaman

3. Hanggar Biliar

4. Kantung Parkir 2

5. Sentra Pedagang Souvenir

6. Kantung Parkir 1

7. Taman Kuliner Pujasewa

8. Toilet umum

9. Pusat Pagelaran Budaya

Pakualaman (Sekarang digunakan sebagai Kampus Akper

Notokusumo).

10. Puri Pangeran

11. Jamu Ginggang

12. Gudeg Permata Bu Narti

13. Museum Pakualam (eks

Bioskop Permata)

: Jalur Andong Wisata (menghubungkan tempat-tempat wisata budaya di Kawasan Wisata Terpadu Pakualaman).

: Jalur masuk dan keluar wisatawan/pengunjung ke Kawasan Wisata Terpadu Pakualaman. 


\section{KESIMPULAN}

Pura Pakualaman dan Kawasan Wisata Pakualaman punya potensi besar yang bisa dikembangkan sebagai produk wisata budaya berbasis budaya kerajaan. Potensi besar ini berupa budaya bersifat tangible (benda), yakni benda-benda atau bangunan-banguna peninggalan Kadipaten Pakualaman yang punya nilai sejarah tinggi, unik dan punya filosofi luhur serta budaya bersifat intangible (non benda), yakni seni tradisi, adat istiadat dan upacaraupacara warisan Kadipaten Pakualaman yang masih dipertahankan kelestariannya. Tidak banyak destinasi budaya di tanah air yang punya potensi berbasis warisan kerajaan seperti yang dimiliki Pura Pakualaman.

Pemanfaatan potensi Pura Pakualaman dan Kampung Wisata Pakualaman untuk pengembangan produk wisata budaya berbasis budaya kerajaan dihadapkan pada banyak kendala dan tantangan, mulai dari konflik antarkerabat Pura Pakualaman, keterbatasan Sumber Daya Manusia (SDM), sistem tata kelola yang belum baik dan belum professional hingga kebijakan Paku Alam X yang belum punya keinginan untuk mengembangkan Pura Pakualaman sebagai destinasi wisata budaya karena masih ingin menjaga privasi sebagai raja.

Perlu strategi pengembangan produk wisata berbasis kerajaan di Pura Pakualaman dan Kampung Wisata Pakualaman yang berkesinambungan, mulai dari program jangka pendek, menengah hingga panjang berdasar analisis SWOT dengan memanfaatkan kekuatan dan peluang sebagai faktor internal untuk mengatasi hambatan dan ancaman sebagai faktor eksternal.

\section{KEPUSTAKAAN}

Kusumo, Angling. 1988. Museum Pura Pakualaman. Yogyakarta: Pura Pakualam.

Rangkuti, Freddy. 1997. Analisis SWOT Teknik Membedah Kasus Bisnis. Jakarta: Gramedia Pustaka Utama.

Robinson dan Pearce, John, 1997. Manajemen Strategi Formulasi, Implementasi, dan Pengendalian. Jakarta: Binarupa Aksara.

Sunaryo, Bambang. 2013. Kebijakan Pembangunan Destinasi Pariwisata Konsep dan Aplikasinya. Yogyakarta: Gava Media.

Suwantoro, Gamal. 2007. Dasar-dasar Pariwisata. Yogyakarta: Andi Offset.

Suryodilogo, Atika, dkk. 2012. Warna Sari Sistem Budaya Kadipaten Pakualaman

Yogyakarta. Jakarta: Trah Pakualaman Hudyana.

Widoyoko. 2017. Teknik Penyusunan Instrumen Penelitian. Yogyakarta: Pustaka Pelajar. 